Canadian

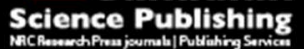

Canadian Journal of Civil Engineering Revue canadienne de génie civil

\title{
Quantification and Comparison of Carbon Emissions for Flexible Underground Pipelines
}

\begin{tabular}{|r|l|}
\hline Journal: & Canadian Journal of Civil Engineering \\
\hline Manuscript ID & cjce-2015-0156.R1 \\
\hline Manuscript Type: & Article \\
\hline Date Submitted by the Author: & $29-J u n-2015$ \\
\hline Complete List of Authors: & $\begin{array}{l}\text { Khan, Lutfor Rahman; Jacobs Engineering Ltd, } \\
\text { Tee, Kong Fah; University of Greenwich, }\end{array}$ \\
\hline Keyword: & $\begin{array}{l}\text { environmental < MANUSCRIPT CLASSIFICATION, hydraulic structures (HS) } \\
\text { < Construction, Engineering Materials }\end{array}$ \\
\hline \multicolumn{2}{|l}{} \\
\hline
\end{tabular}

SCHOLARONE ${ }^{\text {IM }}$

Manuscripts 


\title{
Quantification and Comparison of Carbon Emissions for Flexible
}

\author{
Underground Pipelines \\ Lutfor Rahman Khan ${ }^{1,2}$ and Kong Fah Tee ${ }^{1 *}$ \\ ${ }^{1}$ Faculty of Engineering and Science, University of Greenwich, UK \\ ${ }^{2}$ Rail and Ground Engineering, Jacobs Engineering Ltd, Wokingham, UK
}

\begin{abstract}
The life cycle assessment of underground gravity and pressured pipeline networks are studied to quantitatively calculate the carbon dioxide $\left(\mathrm{CO}_{2}\right)$ emissions. The life cycle of a pipeline can be classified into four phases that are fabrication, transportation, installation and operation. Three typical flexible underground pipe materials, namely, steel, ductile iron (DI) and polyvinyl chloride (PVC) have been considered. The most dominant phase of the life cycle is pipe manufacturing and fabrication process, resulting in large amounts of $\mathrm{CO}_{2}$ emissions. The results indicate that PVC provides the best environmental savings compared to steel and DI pipes in terms of $\mathrm{CO}_{2}$ emission and emission mitigation cost. This methodology in estimating life cycle carbon footprint and cost could be used as managerial decision support tool for management of any underground pipeline networks.
\end{abstract}

Key Words: carbon footprint, buried pipelines, carbon pricing, energy consumption, embodied carbon.

*To whom correspondence should be addressed. Email: K.F.Tee@gre.ac.uk 


\section{Introduction}

The term carbon footprint is commonly used to describe the total amount of carbon dioxide $\left(\mathrm{CO}_{2}\right)$ and other greenhouse gas emissions in a year caused by an organization, event or product. Carbon footprint analysis is becoming more and more popular in every industry due to increasing concerns on global warming and greenhouse gases emissions. $\mathrm{CO}_{2}$ is the main contributor factor and other greenhouse gases, such as methane, nitrous oxide etc. are insignificant. To identify and mitigate this hazard, it is critical to precisely estimate carbon footprints for an engineering project in the initial planning stage. Therefore, it is important to follow a structured methodology and to classify all the possible sources of emissions thoroughly. Like other engineering projects, it is required to identify potential benefits of carbon footprint analysis of underground pipelines and to enforce it as a mandatory practice for waste and water industry. The methodology in estimating life cycle carbon footprint and cost could be used as managerial decision support tool for management of any underground pipeline networks (McDonald and Zhao 2001; Tee and Li, 2011; Khan et al, 2013; Tee et al, 2014a).

A major portion of the underground water and wastewater infrastructure in Europe is rapidly approaching the end of its useful service life and therefore, large scale construction works will need to be undertaken for rehabilitating or renewing these vital infrastructure assets. In the past, various researchers and organizations recognized the importance and the applicability of probabilistic approach in the reliability estimation of buried pipeline systems (Alani et al, 2014; Chughtai and Zayed, 2008; Sivakumar Babu and Srivastava, 2010; Piratla et al, 2012; Tee and Khan, 2012; 2014; Tee et al, 2013; 2014b; 2015). On the other hand, to mitigate $\mathrm{CO}_{2}$ emissions, huge investment will also be needed for the future world. For example, the capital needed for buried infrastructure in the United States from 2000 to 2019 
is approximately $\$ 274$ billion (EPA, 2002). Many countries including UK, are trying to minimise energy consumption and reduce emissions in order to moving toward sustainable development. Therefore, it is essential to monitor the environmental impacts on all underground pipeline infrastructure projects and minimise them whenever possible.

Normally, underground infrastructures are installed using either open cut (cut and cover) or trenchless (cured in place pipe, pipe jacking, pipe bursting, etc.). Open cut construction requires a trench to be excavated to the required depth and width along the entire length of pipeline. On the other hand, trenchless construction methods typically require only minimal excavation (entrance and/or exit pits) or no excavation. According to Adedapo (2012), deflections in trenchless pipes are approximately one-quarter smaller than those induced during open cut-and-cover installation. Moreover, it is possible to defuse environmental and other constraints at an early stage by applying trenchless installation method. Furthermore, the cost for trenchless technique is below the cost for open trench method. However, open cut may appear economical in terms of direct cost but it has high social and environmental costs, such as carbon and greenhouse gas emissions when the construction work is executed in densely populated urban areas (Rehan and Knight, 2007).

The life cycle assessment (LCA) has been applied in evaluating environmental effects to assess the environmental performances. The life cycle activities include extraction of raw materials, manufacturing the pipe used in the project, transportation of pipe to construction site, laying the pipe in the trench, operation and maintenance, dismantling and disposal or recycling the pipe. There are several LCA studies in the wastewater and drinking water infrastructure systems which have been found in literature. Emmerson et al (1995) used the LCA to evaluate the environmental effects of small scale sewage treatment works. Zhang and 
Wilson (2000) performed an LCA analysis for a large sewage treatment plant in Southeast Asia and reinforced the results by Emmerson et al (1995). Skipworth et al (2002) investigated the entire life cycle costs for water distribution systems in the UK. Vidal et al (2002) also used LCA for understanding the environmental consequences for wastewater treatment plant. Filion (2004) developed a LCA model to quantify the energy consumption of a water distribution system in New York tunnels and to compare life cycle energy for different pipe replacement schedules. Their research revealed that the used energy was the primary contributor to environmental burdens and the operational stage of the technologies had the highest share of environmental effects.

Besides that, Dandy et al (2006) developed a water distribution system optimization program that incorporates the sustainability objectives of life cycle costs, energy use, greenhouse gas emissions and resource consumption. Wu et al (2010) developed a multi-objective optimisation procedure to design water distribution systems that minimize the costs and greenhouse gas emissions. Venkatesh et al (2009) studied the contribution of different stages in the life cycle of wastewater pipelines to greenhouse gas emissions. These studies also concluded that energy (i.e., fuel) was an important factor in LCA in the total environmental impacts associated with the plants, where the sewer pipes were made from reinforced concrete, steel, PVC, cast iron and ductile iron; and water distribution pipes were manufactured from steel and ductile irons. A limitation is that these studies did not consider the installation and transportation phase when estimating $\mathrm{CO}_{2}$ emissions. Recio et al (2005) also quantified $\mathrm{CO}_{2}$ life cycle emissions of a pipeline project in Spain through a case study. However, the installation and break repair phases of the pipeline life cycle were not addressed in the analysis. In integrated pipeline (IPL) project (Chilana, 2011), carbon footprint analysis was performed to compare steel and prestressed concrete cylinder pipe 
(PCCP) which is a joint effort between the Tarrant Regional Water District and the City of Dallas. Fuel consumption by construction equipment for installation of pipe in the trench was found to be similar for both steel pipe and PCCP, but PCCP was found to have smaller carbon footprint due to less $\mathrm{CO}_{2}$ emissions in the environment.

To overcome the above limitations and to fill the research gaps, this paper demonstrates a model for assessing, quantifying and comparing life cycle energy consumption and respective $\mathrm{CO}_{2}$ emissions as well as predicting the associated cost values for both gravity and pressured pipelines with addressing four phases of pipe's life cycle that are fabrication, transportation, installation and operation. The life cycle $\mathrm{CO}_{2}$ emissions are quantified and compared among three different pipe materials (steel, DI and PVC). This study made an effort to access quality data on all the life cycle stages based on 150 miles IPL project (Chilana, 2011). In this study, it is assumed that the same length, loading, soil type and pipe laying materials are used in installation phase.

\section{2. $\mathrm{CO}_{2}$ emission estimation}

The life cycle assessment of underground pipeline networks is studied. The $\mathrm{CO}_{2}$ emissions from all the life cycle phases have been quantified and compared among steel, DI and PVC pipes. The energy consumption and $\mathrm{CO}_{2}$ emissions from different life cycle phases depend on the properties of pipe material, type of technologies used (during manufacturing the pipe, installing equipment and pumping technologies) and the type of fluid. Four phases are considered in this life cycle assessment, which are production and fabrication, transportation to job site, pipe installation and operation or service phase. The life cycle period of three different pipes is chosen as 50 years for comparative purpose. However, in reality certain type of pipe, such as PVC can last 100 years whereas other types of pipes need to be replaced 
after 50 years (Piratla et al, 2012). The four phases during service life time of underground pipeline network which are considered in carbon footprint analysis are explained as follows:

\subsection{Material production and pipeline fabrication}

This phase deals with energy consumed during material production and pipeline fabrication (embodied carbon). Embodied energy is the sum of all the energy required to produce any goods or services. The concept can be useful in determining the effectiveness of energyproducing or energy-saving devices to decide whether a product contributes or mitigates global warming. One fundamental purpose for measuring this quantity is to compare the amount of energy produce or save for different product in production and fabrication process. In recent years, the term 'embodied carbon' of construction materials and products has become synonymous with the term 'carbon footprint'. An embodied carbon or carbon footprint assessment is a subset of most LCA studies.

Different methodologies produce different understandings of the scale and scope of application and the type of energy embodied. The embodied energy coefficients proposed by Ambrose et al (2002) are used in this study to quantify the energy consumption of different pipe materials, from raw material extraction phase until the pipes are ready to leave the manufacturing plant. The database entitled "Inventory of Carbon and Energy" (Hammond and Jones, 2008) is used for this analysis. This database provides a cradle-to-gate evaluation of different construction material and summarised the findings in a form of an embodied energy (Mega Joules/kg) for each material as shown in Table 1.

The embodied $\mathrm{CO}_{2}$ emissions for an underground pipeline network can be calculated using Eqs. (1) to (3) as follows (Hammond and Jones, 2008). 
Embodied energy of pipe $=$ Embodied energy coefficient $\mathrm{x}$ weight of pipe material

Total energy consumption $=$ Embodied energy/length $\mathrm{x}$ total length of pipeline

Total $\mathrm{CO}_{2}$ emissions $=$ Total energy consumption $\mathrm{x}$ emissions rate

Equations (1) - (3) show that the embodied energy depends on the pipe materials, length and rate of emissions. Therefore, the choice of materials and size of pipe can significantly change the amount of embodied energy of a pipe, as embodied energy content varies enormously between the product size and materials. Generally, the more highly processed material release higher embodied energy. The embodied energy also may vary with location and time. Moreover, it depends on the material extraction methods, manufacturing methodologies and the type of energy consumed in all the processes. Assessing the embodied energy of a material is often a complex task. Lightweight pipe materials such as PVC pipes are usually lower in embodied energy than heavyweight pipes, such as steel and ductile iron (Adams et al, 2006).

\subsection{Pipe transportation to job site}

This phase includes the calculation of total fuel consumption during transporting the pipe to job site. The contribution of $\mathrm{CO}_{2}$ emission from transporting the pipe is calculated on total distance basis. The truck-trailer combination unit is selected on the basis of the length and weight of each pipe section. Total number of pipe sections and the number of truck-trailer unit can be calculated by Eqs. (4) and (5). Fuel consumption is calculated on the basis of mileage which is considered as 5.40 miles per gallon (Transportation Energy Data Book, 2010) for each truck-trailer as illustrated in Eqs. (6) and (7). Total fuel consumption is then converted into the $\mathrm{CO}_{2}$ emissions by using an emission factor of $10.1 \mathrm{~kg} \mathrm{CO}_{2}$ per gallon of diesel fuel (EPA, 2005) as shown in Eq. (8). 
Total number of pipe sections $=$ Total length of pipeline/length of each pipe section

Total number of truck-trailer units $=$ Total length of pipeline/length of pipe on one unit

Fuel consumption for each truck-trailer unit $=$ Distance to be covered $/$ mileage

Total fuel consumption $=$ Fuel consumption for one unit $\mathrm{x}$ total number of units

Total $\mathrm{CO}_{2}$ emissions $=$ Total fuel consumption (gallons) $\times 10.1 \mathrm{Kg} \mathrm{CO}_{2} /$ gallon

\subsection{Pipe installation in trench}

Pipe installation is a time consuming process. Normally, the installed process consists of trench excavation, pipe laying, compaction, material screening, trench support, water sparking and backfilling. However, in this study, only major construction activities are considered, such as excavation, pipe laying and backfilling. The installation process involves laying the pipe underground with a set of construction equipment. The installation equipment needs to be transported to the site along with the pipe. The production rate of any construction methods or equipment depends on several factors. Most of the construction equipment uses diesel as a fuel which causes $\mathrm{CO}_{2}$ emissions. As discussed earlier, the installation process can be open cut or trenchless. However, only open cut method is considered in this article. The installation of pipelines using open cut methods involves the use of construction machinery, such as, excavators, backhoes, loaders, hauling trucks, etc. To determine $\mathrm{CO}_{2}$ emissions from heavy construction equipment, the time duration for which any piece of equipment is operated has to be determined to predict the associated fuel consumption. Peurifoy et al (2002) indicates that fuel consumption of construction equipment can range from one gallon per hour to 11.5 gallons per hour depending on the equipment utilization - low, medium or high. For this analysis, a fuel consumption rate of 2.4 gallons per hour has been used to determine the amount of $\mathrm{CO}_{2}$ generated. The fuel consumption is then 
converted to $\mathrm{kg}$ of $\mathrm{CO}_{2}$ using $10.1 \mathrm{~kg}$ of $\mathrm{CO}_{2}$ for each gallon of diesel fuel used according to EPA (2005).

\subsection{Operation or usage phase of pipeline}

The usage phase of a pipeline can be divided into three categories when accounting for the $\mathrm{CO}_{2}$ emissions. First, for pressured pipes, liquid needs to be pumped to a certain pressure head and flow rate using pumps, typically centrifugal, which involves energy consumption and $\mathrm{CO}_{2}$ emissions. On the other hand, for gravity sewerage pipes, there is no need any pumping and therefore, energy consumption due to pumping is ignored over the life cycle of pipes. Liquid must be pumped at a pressure greater than a minimum required pressure $H_{s}$. Friction losses $\left(H_{f}\right)$ also must be considered all along the length of the pipe. These are calculated using Hazen-Williams equation. All plastic pipes are corrosion-free, whereas metal (steel, cast iron, ductile iron etc.) pipes require corrosion protection. Sharp and Walski (1988) proposed the following roughness growth model as shown in Eqs. (9) and (10) to predict the change in the Hazen-Williams friction coefficient, $C$ due to corrosion with the age of the pipe as follows.

$C=18-37.2 \log X$

$X=\left(e_{0}+a t\right) / D_{0}$

where $X$ is relative roughness of pipe, $e_{0}$ is initial wall roughness at the time when pipe is installed, $a$ is roughness height growth rate, $T$ is time in years and $D_{0}$ is outside diameter of pipe. Subsequently, the energy requirements can be calculated using Eq. (11).

The Hazen-Williams coefficient relates to the flow of water in a pipe with physical properties of the pipe materials and the pressure drop caused by friction. It is used in the design of water 
pipe systems, such as water supply networks, fire sprinkler systems and irrigation systems. The Hazen-Williams coefficient is mainly influenced by corrosion on pipe wall. Therefore, the more corrosion prone material shows higher $\mathrm{C}$ value and emits more $\mathrm{CO}_{2}$ in the environment. For example, steel pipe shows higher $\mathrm{C}$ value than ductile iron pipe. There is no corrosion in plastic pipe and therefore $\mathrm{C}$ value for plastic pipe material is zero.

$\operatorname{Power}(k W)=\rho g H Q / 1618.5 \eta$

where $Q$ is flow rate in gallons per minute and $H$ is $H_{s}+H_{f} . H_{s}$ is pumped pressure head and $H_{f}$ is head loss which can be estimated using Eq. (12) as follows.

$H_{f}=0.002083 L(100 / C)^{1.85}\left(\frac{Q^{1.85}}{D_{0}^{4.8655}}\right)$

where $L$ is length of pipe. Eq. (11) can be rewritten as shown in Eq. (13) after adjusting the units as follows

Energy $(\mathrm{kWh})=\int_{0}^{T} \frac{\left(H_{s}+H_{f}\right) Q \times S . G}{1618.5 \eta} d t$

where $S . G$ is specific gravity of fluid and $\eta$ is pump efficiency.

The energy consumed is obtained by multiplying the power with the number of working hours. The $\mathrm{CO}_{2}$ emissions are calculated using an emission factor $\left(\mathrm{kgCO}_{2} / \mathrm{kWh}\right)$ because most of the centrifugal pumps use electricity to power the engines. The total amount of energy consumed and the $\mathrm{CO}_{2}$ emissions released is from pumping liquid (mainly water) through the pipeline. 
The second category in the usage phase of a pipe's life cycle is cleaning and inspection works which is not considered in this study due to the insignificance of $\mathrm{CO}_{2}$ emissions compared to other phases of the service life. The third category is pipe failure or break repair over the life cycle of the pipe. It is unlikely that the pipe needs to be replaced or repaired within the considered working life (50 years). Therefore, the emitted carbons for this category are also considered negligible in this study.

\section{Carbon pricing}

The carbon price is based on the social cost of carbon which normally refers to the cost to mitigate climate change or the marginal social damage from 1 ton of emitted carbon (Guo et al, 2006). However, the actual carbon price is often determined by the market value (Prime Ministerial Task Group on Emissions Trading, 2007). The average world market price of 1 ton of greenhouse gases in the form of $\mathrm{CO}_{2}$-e in 2005-2006 was around U.S. \$20 to \$25 (Wu et al, 2010). In order to achieve long-term abatement, the carbon price is expected to rise over time. In the literature, there are many estimates of possible future carbon prices based on different scenarios. The Australian Bureau of Agricultural and Resource Economics estimates carbon prices to range from Australian $\$ 28$ to $\$ 46 / \mathrm{t}$ of $\mathrm{CO}_{2}$-e for an international market and from $\$ 15$ to $\$ 31 /$ t of $\mathrm{CO}_{2}$-e for an Australian abatement market in 2030 (Prime Ministerial Task Group on Emissions Trading, 2007). However, the actual social cost of carbon could be higher. Sterner and Persson (2008) suggested that a marginal social cost of carbon could reach over U.S. $\$ 400 / t$ of carbon by 2050 which is equivalent to about U.S. $\$ 110$ or $\$ 120 / t$ of $\mathrm{CO}_{2}$-e. It should be noted that actual market carbon prices will vary with time. However, the constant carbon price of $£ 10 /$ ton of $\mathrm{CO}_{2}$-e has been adopted in this paper to sufficiently illustrate the impact that different carbon prices are likely to have on the trade-offs between cost and $\mathrm{CO}_{2}$ emissions, as these cover the likely range of expected values. 


\section{Implementation of the method}

To facilitate the calculations for various scenarios, a spread sheet was developed using the foregoing discussions in Sections 2 and 3. The utility of this model is demonstrated through the use of case studies where $\mathrm{CO}_{2}$ emissions are quantified and compared for different pipe materials and different phases. The installation of pipelines is completed using heavy machinery that consumes diesel fuel. Davis and Diegel (2007) indicate that commercial diesel fuel equipment generates more $\mathrm{CO}_{2}$ than non-commercial gasoline vehicles. According to EPA (2005), $10.1 \mathrm{~kg}$ of $\mathrm{CO}_{2}$ is generated for each gallon of diesel fuel consumption.

Pipes with the same length and nominal diameter are considered for comparative study of environmental effects. The pipe properties are shown in Table 2 where the pipes' mean thickness and weight are obtained from the manufacturer's manuals, ASCE (2001). Minimum required pumped pressure head, $H_{s}=49.3 \mathrm{~m}$ is considered over 50 years of service life for pressured pipes where operating time is 6 hours per day. All plastic pipes are corrosion-free, so Hazen-Williams friction coefficient, $C$ is zero. The typical $C$ values are 160 and 150 for steel and ductile iron pipes, respectively in this study. The average value of $e_{0}=0.114 \mathrm{~mm}$ is found for both metal pipes. Subsequently, the growth rate, $a$ is calculated as $0.08 \mathrm{~mm} / \mathrm{year}$ for the metal pipes. The flow rate, $Q$ for all types of pipes is assumed as $1 \mathrm{~m} / \mathrm{s}$ and the pumping efficiency, $\eta$ is $75 \%$.

\section{Results and Discussion}

Different pipe materials have different manufacturing processes and thus result in different embodied energy values. This is caused by the difference in densities of the three materials. The embodied energy also may vary with location and time depending on the material 
extraction methods, manufacturing technologies and the type of energy consumed in all the processes. Table 3 presents $\mathrm{CO}_{2}$ emissions in manufacturing and fabrication process for different pipe materials used in the study. Different countries released different state level electricity and heat generation emission factors for calculation of carbon footprint. The emission rates for the usage of electricity and heat (due to natural gas combustion) in the UK are $0.52 \mathrm{kgCO}_{2} / \mathrm{kWh}$ and $0.185 \mathrm{kgCO}_{2} / \mathrm{kWh}$, respectively (DEFRA, 2013). These emission rates are used for the prediction of $\mathrm{CO}_{2}$ emissions due to electricity and heat in the manufacturing and fabrication process as required in Eq. (3).

EPA (2005) method is used to calculate the $\mathrm{CO}_{2}$ due to transportation of pipe to the site. According to EPA (2005), transportation using trucks generally consumes energy in the form of diesel and releases $\mathrm{CO}_{2}$ emissions. In this process, the distance travelled from the manufacturing plant to the local distributor plus the distance from distributor to the project site is taken as the total distance covered by a truck to deliver the pipe to the project site. The emission calculator has a provision to quantify $\mathrm{CO}_{2}$ emissions resulting from transportation trucks. The transportation requirements and the travel distances for this study are listed in Table 4. It is assumed that the weight of each vehicle is approximately equal for all the calculations. The emitted $\mathrm{CO}_{2}$ due to transportation is predicted using Eq. (8).

Tables $5-7$ present the details of the equipment usage requirements for installing the pipes as used by Chilana (2011). The total installation time spent on site (hours) are calibrated based on IPL project. Different models of equipment are used during installation, namely, Komatsu, Caterpillar, Trencor and John Deere. The equipment can be used to install any pipe materials considered in the case study and it is assumed that the amount of $\mathrm{CO}_{2}$ emission is the same for all cases. For this analysis a fuel consumption rate of 2.4 gallons per hour has 
been used to determine the amount of $\mathrm{CO}_{2}$ generated. The fuel consumption is converted to $\mathrm{kg}$ of $\mathrm{CO}_{2}$ using $10.1 \mathrm{~kg}$ of $\mathrm{CO}_{2}$ for each gallon of diesel fuel used.

The emitted $\mathrm{CO}_{2}$ from different phases of pipe life cycle for different pipe materials are shown in Figures $1-4$ due to manufacturing and fabrication, transportation, installation and pumping, respectively. Figures $1-3$ present LCA for both gravity and pressured pipeline networks whereas Fig. 4 shows the $\mathrm{CO}_{2}$ emission due to pumping for pressured pipelines. Figure 3 shows that $\mathrm{CO}_{2}$ emissions in steel pipes are greater than DI and PVC pipes. This is caused by the difference in densities of the pipes materials. It is observed that in gravity pipeline system, the most dominant phase of the life cycle is pipe manufacturing and fabrication process, resulting in large amounts of $\mathrm{CO}_{2}$ emissions. On the other hand, besides manufacturing and fabrication, the dominating phase for pressured pipelines also includes operation phase. It is found that the fuel consumption during the transportation is directly proportional to the weight and length of each pipe section as well as the distance between the manufacturing plant and the job site.

Normally, the pump operating time is considered 6 to 8 hours daily throughout the service life of pipe (Piratla et al, 2012). However, the operating time is varied over the day. The demand for pumping is high from $6 \mathrm{AM}-9 \mathrm{AM}, 1 \mathrm{PM}-2 \mathrm{PM}$ and 7PM - 9PM which are considered in this study. The emitted $\mathrm{CO}_{2}$ due to pumping on hourly basis over the service life is shown in Fig. 5. The result shows that pumping energy is required the most in the early morning. In the operation phase, besides pumping, all other activities consume negligible energy and produce insignificant $\mathrm{CO}_{2}$ emissions within 50 years of life cycle time for both gravity and pressured pipelines. At the end of the life cycle (i.e., when the pipe is no longer 
suitable for meeting its intended function), the pipe is removed and disposed, recycled or abandoned.

The $\mathrm{CO}_{2}$ emissions from different phases of the life cycle have been added. Tables $8-9$ present and compare the total life cycle emissions with different pipe materials (steel, DI and PVC) for gravity and pressured pipelines, respectively. Result indicates that PVC pipes have the least $\mathrm{CO}_{2}$ emissions compared to steel and DI pipes. However, PVC pipes are not strong enough to support mechanical stresses as those of steel and DI. PVC pipes offer great advantage in environments that PVC is a non-corrosive material. Besides that, unit weight of PVC pipe is significantly lower than steel and DI pipes as shown in Table 2. Thus, PVC pipe produces lower $\mathrm{CO}_{2}$ emissions that contribute to global warming. On the other hand, steel and DI iron pipes' primary advantage is their mechanical strength. Steel and ductile iron pipes have higher material strength for handling external dead and live loading and better distribution of thrust or pulling forces around the soil. However, these are corrosive and heavy metal pipes which produce higher $\mathrm{CO}_{2}$ emissions and contribute to global warming.

Finally the $\mathrm{CO}_{2}$ emission mitigation has been estimated according to Carbon (2008) with average price of $£ 10 /$ ton in European Union (EU) region. The results demonstrate that steel pipe requires more carbon emission cost compared to DI and PVC pipes whereas PVC pipe has the least carbon emission cost. The analyses of $\mathrm{CO}_{2}$ emissions for steel, DI and PVC pipes have a reasonable agreement with those obtained from Chilana (2011) and Piratla et al (2012).

Note that the $\mathrm{CO}_{2}$ emission due to above mentioned phases of pipeline is variable with time and the modelling of $\mathrm{CO}_{2}$ emissions is uncertain. Therefore, there are some sets of broad 
principles should be followed during measuring and reporting $\mathrm{CO}_{2}$ emission such as International Organisation for Standardisation and the Carbon Trust Standard. The guidance includes:

i. Company or manufacturer information

ii. $\quad$ Reporting period

iii. The reason for any significant changes in emissions since previous year

iv. The measuring and reporting approach

v. List specifying the activity types included in each phase

vi. Detail of any specific exclusions of emissions from any phase of pipeline

vii. The conversion tools for emission factors

viii. Breakdown by country of total GHG emissions (geographical breakdown)

ix. Detail of any exclusions of countries if a global total is reported

x. The base year chosen and approach used to set the base year and base year recalculation policy

xi. Calculation methodologies for each activity, etc.

\section{Conclusions}

An analysis has been conducted to understand the implication of carbon footprint by quantifying the $\mathrm{CO}_{2}$ emissions for three flexible underground pipe materials that are steel, ductile iron and PVC. An example is presented to validate the proposed method for both gravity and pressured pipelines. It is observed that in both gravity and pressured pipeline systems, the most dominant phase of the life cycle is pipe manufacturing and fabrication process, resulting in large amounts of $\mathrm{CO}_{2}$ emissions. Analysis shows that PVC pipes have the least $\mathrm{CO}_{2}$ emissions cost. It is important to quantify $\mathrm{CO}_{2}$ emissions in order to achieve the predetermined emission reduction targets. Environmental impacts depend upon the system 
boundaries selected and the product inventory data varies from country to country. This research could be used as a managerial decision support tool for utility projects. It is recommended that more field studies should be conducted in the future to acquire the necessary data to increase reliability on the assumptions made in this research.

\section{References}

Adams E, Connor J and Ochsendorf J. 2006. Embodied energy and operating energy for buildings: cumulative energy over time. Design for sustainability. Civil and Environmental Engineering, Massachusetts Institute of Technology, Cambridge, MA.

Adedapo A. 2012. Direct comparison of HDD and open-cut pipe installation underneath flexible pavement: pavement and pipe performance evaluation. Department of Civil Engineering, University of Waterloo, Canada.

Alani AM, Faramarzi A, Mahmoodian M and Tee KF. 2014. Prediction of sulphide build-up in filled sewer pipes. Environmental Technology, 35(14), 1721-1728.

ASCE (American Society of Civil Engineers). 2001. Guidelines for the design of buried steel pipe. American Lifeline Alliance and ASCE, USA, 9-20.

Carbon. 2008. Carbon Market Insights. Point Carbon's $5^{\text {th }}$ annual conference, 11 - 13 March, Copenhagen, Netherland.

Chilana L. 2011. Carbon footprint analysis of large diameter water transmission pipeline installation. UMI dissertation publishing, the University of Texas at Arlington, USA 
Chughtai $\mathrm{F}$ and Zayed T. 2008. Infrastructure condition prediction models for sustainable sewer pipelines. Journal of Performance of Constructed Facilities, 22(5), 333-341.

Colombo AF, and Karney BW. 2002. Energy and costs of leaky pipes: Toward comprehensive picture. J. Water Resour. Plann. Manage., 128(6), 441-450.

Dandy G, Roberts A, Hewitson C and Chrystie P. 2006. Sustainability objectives for the optimization of water distribution networks. Proc., WDSA 2006, ASCE, Reston, VA, 1-11.

Davis SC. and Diegel SW. 2010. Transportation Energy Data Book: Edition 29, Oak Ridge National Laboratory U.S. Department of Energy Center for Transportation Analysis Engineering Science \& Technology Division.

DEFRA (Department for Environment Food and Rural Affairs). 2013. Government GHG Conversion Factors for Company Reporting: Methodology Paper for Emission Factors, UK.

EPA (Environmental Protection Agency). 2002. The clean water and drinking water infrastructure gap analysis. Washington DC. USA.

EPA (Environmental Protection Agency). 2005. Average Carbon Dioxide Emissions Resulting from Gasoline and Diesel Fuel. Washington DC, USA. 
Emmerson RHC, Morse GK, Lester JN and Edge DR. 1995. The life-cycle analysis of small scale sewage-treatment processes. Journal of Inst. Water Environmental Management, 9, $317-325$.

Filion YR, MacLean HL and Karney BW. 2004. Life cycle energy analysis of a water distribution system. Journal of Infrastructure System. 10(3), 120-130.

Hammond GP and Jones CI. 2008. Inventory of carbon \& energy (ICE), University of Bath, UK.

Khan LR, Tee KF and Alani AM. 2013. Reliability-based management of underground pipeline network using genetic algorithm, Proc. of the $11^{\text {th }}$ International Probabilistic Workshop, Brno, Czech Republic, November 6-8, 159-170.

McDonald S and Zhao J. 2001. Condition assessment and rehabilitation of large sewers. Proc. of the International Conference on Underground Infrastructure Research, Univ. of Waterloo, Waterloo, Canada, 361-369.

Peurifoy RL, Ledbetter WB and Schexnayder CJ. 2002. Construction planning, equipment, and methods. 6th ed. McGraw-Hill, New York.

Piratla KR, Ariaratnam ST and Cohen A. 2012. Estimation of CO2 emissions from the life cycle of a potable water pipeline project, Journal of Management in Engineering, ASCE, $28(1), 22-30$. 
Prime Ministerial Task Group on Emissions Trading 2007. Australia.

Recio JMB, Guerrero PJ, Ageitos MG. and Narváez RP. 2005. Estimate of energy consumption and $\mathrm{CO}_{2}$ associated with the production, use and disposal of PVC, HDPE, PP, ductile iron and concrete pipes. Universitat Politècnica de Catalunya, Barcelona, Spain.

Rehan R and Knight M. 2007. Do Trenchless Pipeline Construction Methods Reduce Greenhouse Gas Emissions. Preliminary Report, Centre for the Advancement of Trenchless Technologies, Waterloo University, Canada

Sivakumar Babu GL and Srivastava A. 2010. Reliability analysis of buried flexible pipe-soil systems. Journal of Pipeline Systems Engineering and Practice, ASCE, 1(1), 33-41.

Skipworth P, Engelhardt M, Cashman A, Savic D, Saul A and Walters G. 2002. Whole life costing for water distribution network management, Thomas Telford, London.

Tee KF and Khan LR. 2012. Risk-cost optimization and reliability analysis of underground pipelines. Proc. of the $6^{\text {th }}$ International ASRANet Conference, London, UK, July 2-4, Paper 49.

Tee KF and Khan LR. 2014. Reliability analysis of underground pipelines with correlation between failure modes and random variables. Journal of Risk and Reliability, Proceedings of the Institution of Mechanical Engineers, Part O, 228(4), 362-370. 
Tee KF and Li CQ. 2011. A numerical study of maintenance strategy for concrete structures in marine environment. Proc. of the $11^{\text {th }}$ International Conference on Applications of Statistics and Probability in Civil Engineering, Zurich, Switzerland, August 1-4, 618-625.

Tee KF, Khan LR and Chen HP. 2013. Probabilistic failure analysis of underground flexible pipes. Structural Engineering and Mechanics, 47(2), 167-183.

Tee KF, Khan LR, Chen HP and Alani AM. 2014a. Reliability based life cycle cost optimization for underground pipeline networks. Tunnelling and Underground Space Technology, 43, 32-40.

Tee KF, Khan LR and Li HS. 2014b. Application of subset simulation in reliability estimation for underground pipelines, Reliability Engineering and System Safety, 130, 125 131.

Tee KF, Khan LR and T.Coolen-Maturi. 2015. Application of receiver operating characteristics curve for pipeline reliability analysis. Journal of Risk and Reliability, Proceedings of the Institution of Mechanical Engineers, Part O, 229(3), 181-192.

Venkatesh G, Hammervold J and Brattebo H. 2009. Combined MFA-LCA for analysis of wastewater pipeline networks: Case study of Oslo (Norway). J. Ind. Ecol., 13(4), 532-550.

Vidal N, Poch M, Marti E and Rodriguez-Roda I. 2002. Evaluation of the environmental implications to include structural changes in a wastewater treatment plant. J. Chem. Technol. Biotechnol., 77(11), 1206-1211. 
Wu W, Maier HR and Simpson AR. 2010. Single-objective versus multi-objective optimization of water distribution systems accounting for greenhouse gas emissions by carbon pricing. J. Water Resour. Plann. Manage., 136(5), 555-565.

Zhang Z and Wilson F. 2000. Life cycle assessment of a sewage treatment plant in SouthEast Asia. J. Inst. Water Environ. Manage., 14(1), 51-56. 
Table 1: Embodied energy coefficients for pipe materials

\begin{tabular}{|c|c|}
\hline Pipe component materials & Embodied energy coefficient \\
\cline { 2 - 2 } & Mega Joules $/ \mathrm{kg}$ \\
\hline Steel pipe & 34.40 \\
\hline Ductile Iron pipe & 38.20 \\
\hline PVC & 78.90 \\
\hline
\end{tabular}

Table 2: Pipe properties

\begin{tabular}{|c|c|c|c|c|}
\hline Pipe materials & $\begin{array}{c}\text { Length } \\
(\mathrm{m})\end{array}$ & $\begin{array}{c}\text { Diameter } \\
(\mathrm{mm})\end{array}$ & $\begin{array}{c}\text { Mean thickness } \\
(\mathrm{mm})\end{array}$ & $\begin{array}{c}\text { Weight } \\
(\mathrm{kg} / \mathrm{m})\end{array}$ \\
\hline Steel & 150000 & 400 & 12 & 114.7 \\
\hline Ductile Iron & 150000 & 400 & 9 & 80.7 \\
\hline PVC & 150000 & 400 & 20 & 37.9 \\
\hline
\end{tabular}

Table 3: $\mathrm{CO}_{2}$ emissions in manufacturing and fabrication process

\begin{tabular}{|c|c|c|c|}
\hline Pipe types & $\mathrm{CO}_{2}$ for electricity $(\mathrm{kg})$ & $\mathrm{CO}_{2}$ for heat $(\mathrm{kg})$ & Total $\mathrm{CO}_{2}(\mathrm{~kg})$ \\
\hline Steel & 83930218.5 & 30445275.0 & 114375493.5 \\
\hline Ductile Iron & 65553053.9 & 23779048.2 & 89332102.1 \\
\hline PVC & 60370847.8 & 21478090.0 & 81848937.8 \\
\hline
\end{tabular}


Table 4: Total $\mathrm{CO}_{2}$ emission for pipe transportation

\begin{tabular}{|c|c|c|c|c|}
\hline \multirow[t]{2}{*}{ Description } & \multirow[t]{2}{*}{ Unit } & \multicolumn{3}{|c|}{ Pipeline segments } \\
\hline & & Steel & Ductile Iron & $\mathrm{PVC}$ \\
\hline $\begin{array}{l}\text { Diameter of each pipe } \\
\text { section }\end{array}$ & $\mathrm{mm}$ & 400 & 400 & 400 \\
\hline $\begin{array}{l}\text { Weight of each pipe } \\
\text { section }\end{array}$ & $\mathrm{kg}$ & 17208576 & 12103600.5 & 5685000 \\
\hline $\begin{array}{l}\text { Length of each pipe } \\
\text { section }\end{array}$ & metre & 50 & 50 & 50 \\
\hline Length of each pipe & metre & 1500000 & 150000 & 150000 \\
\hline $\begin{array}{l}\text { Distance between the } \\
\text { plant \& center point of } \\
\text { the segment }\end{array}$ & kilometre & 100 & 140 & 130 \\
\hline $\begin{array}{l}\text { Number of pipe sections } \\
\text { carried by each truck- } \\
\text { trailer }\end{array}$ & Ea. & 1 & 1 & 1 \\
\hline $\begin{array}{l}\text { Total number of truck- } \\
\text { trailer required }\end{array}$ & Ea. & 3000 & 3000 & 3000 \\
\hline $\begin{array}{l}\text { Mileage for each truck- } \\
\text { trailer }\end{array}$ & miles/gal. & 5.4 & 5.4 & 5.4 \\
\hline $\begin{array}{l}\text { Total diesel } \\
\text { consumption for } \\
\text { each truck-trailer }\end{array}$ & gallon & 18.5 & 25.9 & 24 \\
\hline $\begin{array}{l}\text { Total diesel required for } \\
\text { all truck-trailers }\end{array}$ & gallon & 55500 & 7770 & 72000 \\
\hline $\begin{array}{l}\mathrm{CO}_{2} \text { emission from each } \\
\text { gallon of diesel fuel }\end{array}$ & $\mathrm{kg} / \mathrm{gal}$ & 10.1 & 10.1 & 10.1 \\
\hline $\begin{array}{l}\text { Total } \mathrm{CO}_{2} \text { emission } \\
\text { from the diesel fuel } \\
\text { consumption }\end{array}$ & $\mathrm{kg}$ & 561111 & 785555.5 & 729444 \\
\hline
\end{tabular}


Table 5: Productivity for Excavation

\begin{tabular}{|c|c|c|c|c|c|c|}
\hline $\begin{array}{l}\text { Type of } \\
\text { work }\end{array}$ & Equipment & Model & Pipe Materials & $\begin{array}{l}\text { Total time } \\
\text { spent on } \\
\text { site (hours) }\end{array}$ & $\begin{array}{l}\text { Usage } \\
(\%)\end{array}$ & $\begin{array}{l}\text { Actual } \\
\text { time spent } \\
\text { (hours) }\end{array}$ \\
\hline \multirow[t]{9}{*}{ Excavation } & \multirow[t]{3}{*}{ Komatsu } & \multirow[t]{3}{*}{ PC 1250} & Steel & 2049 & \multirow[t]{3}{*}{$90 \%$} & 1844 \\
\hline & & & DI & 2049 & & 1844 \\
\hline & & & PVC & 2049 & & 1844 \\
\hline & \multirow[t]{3}{*}{ Caterpillar } & \multirow[t]{3}{*}{$385 \mathrm{~B}$} & Steel & 328 & \multirow[t]{3}{*}{$50 \%$} & 164 \\
\hline & & & DI & 328 & & 164 \\
\hline & & & PVC & 328 & & 164 \\
\hline & \multirow[t]{3}{*}{ Trencor } & \multirow[t]{3}{*}{1760} & Steel & 1366 & \multirow[t]{3}{*}{$100 \%$} & 1366 \\
\hline & & & DI & 1366 & & 1366 \\
\hline & & & PVC & 1366 & & 1366 \\
\hline \multicolumn{6}{|c|}{ Total } & 10125 \\
\hline
\end{tabular}

Table 6: Productivity for Pipe Laying

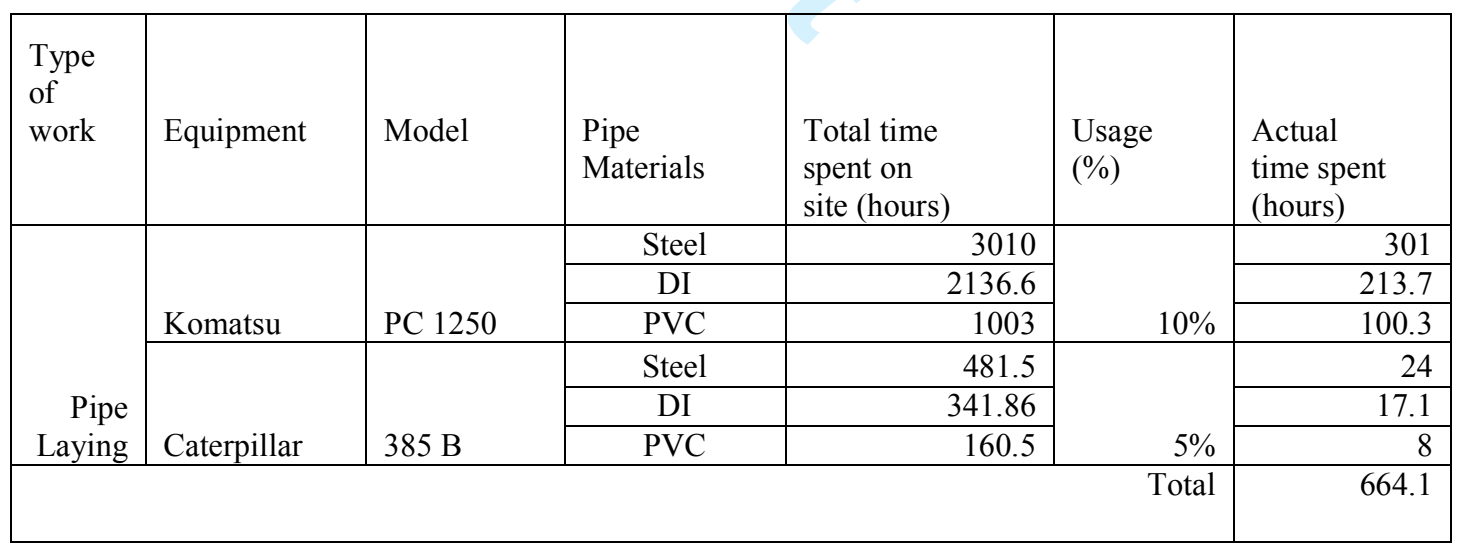


Table 7: Productivity for Backfilling

\begin{tabular}{|c|c|c|c|c|c|c|}
\hline $\begin{array}{l}\text { Type of } \\
\text { Work }\end{array}$ & Equipment & Model & & $\begin{array}{l}\text { Total time } \\
\text { spent on } \\
\text { site (hours) }\end{array}$ & $\begin{array}{l}\text { Usage } \\
(\%)\end{array}$ & $\begin{array}{l}\text { Actual } \\
\text { time spent } \\
\text { (hours) }\end{array}$ \\
\hline \multirow{15}{*}{ Backfilling } & \multirow{3}{*}{ Caterpillar } & \multirow{3}{*}{$385 \mathrm{~B}$} & Steel & 328 & \multirow{3}{*}{$30 \%$} & 98.4 \\
\hline & & & DI & 328 & & 98.4 \\
\hline & & & $\mathrm{PVC}$ & 328 & & 98.4 \\
\hline & \multirow{3}{*}{ John Deere } & \multirow{3}{*}{ 450D LC } & Steel & 2254 & \multirow{3}{*}{$100 \%$} & 2254 \\
\hline & & & DI & 2254 & & 2254 \\
\hline & & & $\mathrm{PVC}$ & 2254 & & 2254 \\
\hline & \multirow{3}{*}{ John Deere } & \multirow{3}{*}{$850 \mathrm{~J}$} & Steel & 1434 & \multirow{3}{*}{$10 \%$} & 143.4 \\
\hline & & & DI & 1434 & & 143.4 \\
\hline & & & $\mathrm{PVC}$ & 1434 & & 143.4 \\
\hline & \multirow{3}{*}{ John Deere } & \multirow{3}{*}{$650 \mathrm{~J}$} & Steel & 574 & \multirow{3}{*}{$10 \%$} & 57.4 \\
\hline & & & DI & 574 & & 57.4 \\
\hline & & & $\mathrm{PVC}$ & 574 & & 57.4 \\
\hline & \multirow{3}{*}{ John Deere } & \multirow{3}{*}{$550 \mathrm{~J}$} & Steel & 164 & \multirow{3}{*}{$10 \%$} & 16.4 \\
\hline & & & DI & 164 & & 16.4 \\
\hline & & & $\mathrm{PVC}$ & 164 & & 16.4 \\
\hline & & & & & Total & 7710.93 \\
\hline
\end{tabular}

Table 8: Total $\mathrm{CO}_{2}$ emissions and prices for gravity pipeline network

\begin{tabular}{|c|c|c|}
\hline Pipe material & Total emission $(\mathrm{Kg})$ & Price $(£ \mathrm{~m})$ \\
\hline Steel & $12.0 \mathrm{E}+07$ & 1.2 \\
\hline Ductile iron & $9.02 \mathrm{E}+07$ & 0.9 \\
\hline PVC & $8.46 \mathrm{E}+07$ & 0.846 \\
\hline
\end{tabular}

Table 9: Total $\mathrm{CO}_{2}$ emission and prices for pressured pipeline network

\begin{tabular}{|c|c|c|}
\hline Pipe material & Total emission $(\mathrm{Kg})$ & Price (£m) \\
\hline Steel & $12.21 \mathrm{E}+07$ & 1.22 \\
\hline Ductile iron & $9.180 \mathrm{E}+07$ & 0.918 \\
\hline PVC & $8.4 \mathrm{E}+07$ & 0.84 \\
\hline
\end{tabular}




\section{LIST OF FIGURE CAPTIONS}

Fig. 1: $\mathrm{CO}_{2}$ emissions from manufacturing and fabrication for different pipe materials

Fig. 2: $\mathrm{CO}_{2}$ emissions from pipe transportation for different pipe materials

Fig. 3: $\mathrm{CO}_{2}$ emissions from pipe installation for different pipe materials

Fig. 4: $\mathrm{CO}_{2}$ emissions from pumping for different pipe materials

Fig. 5: $\mathrm{CO}_{2}$ emissions at different times of day for different pipe materials 


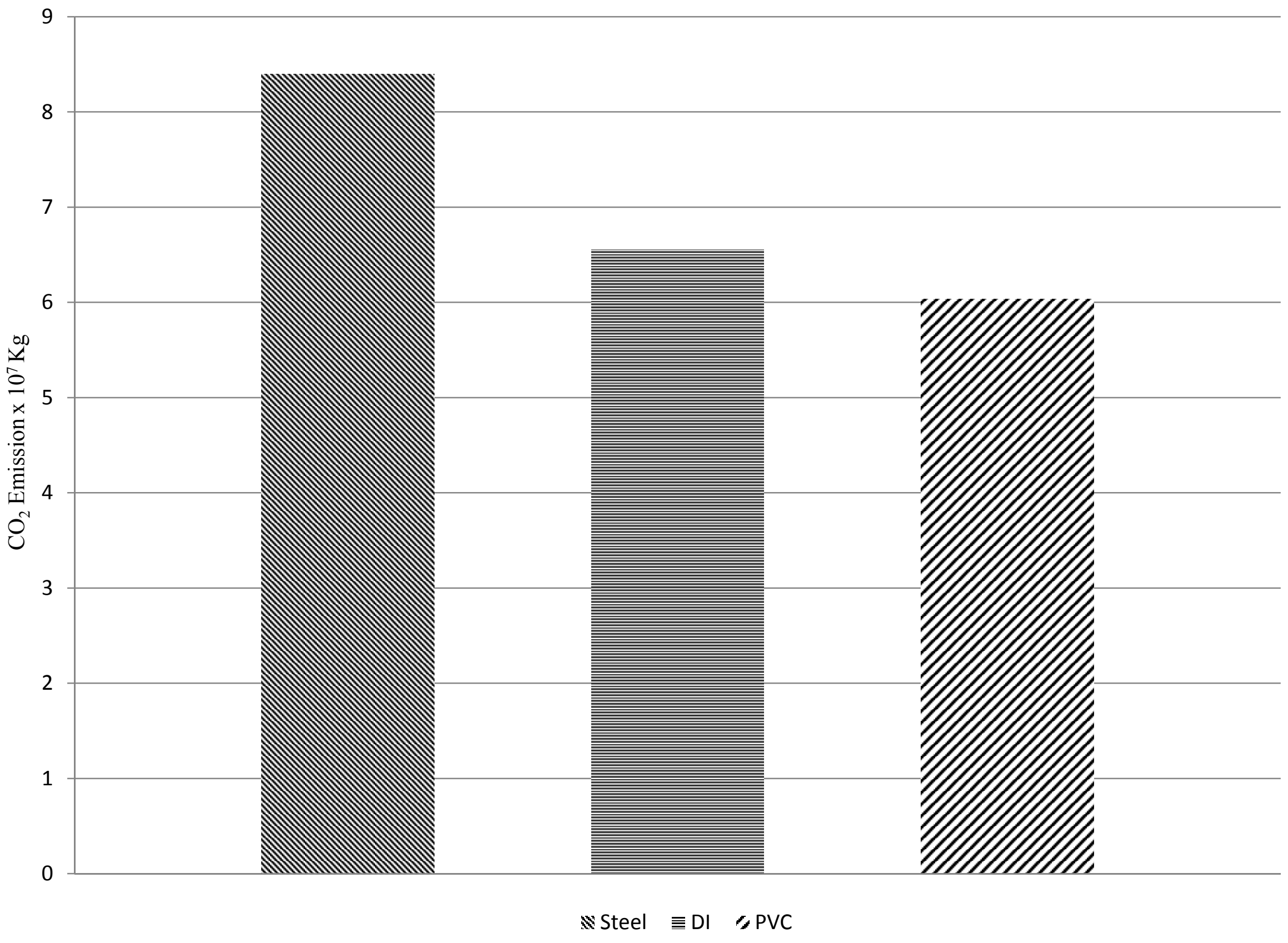




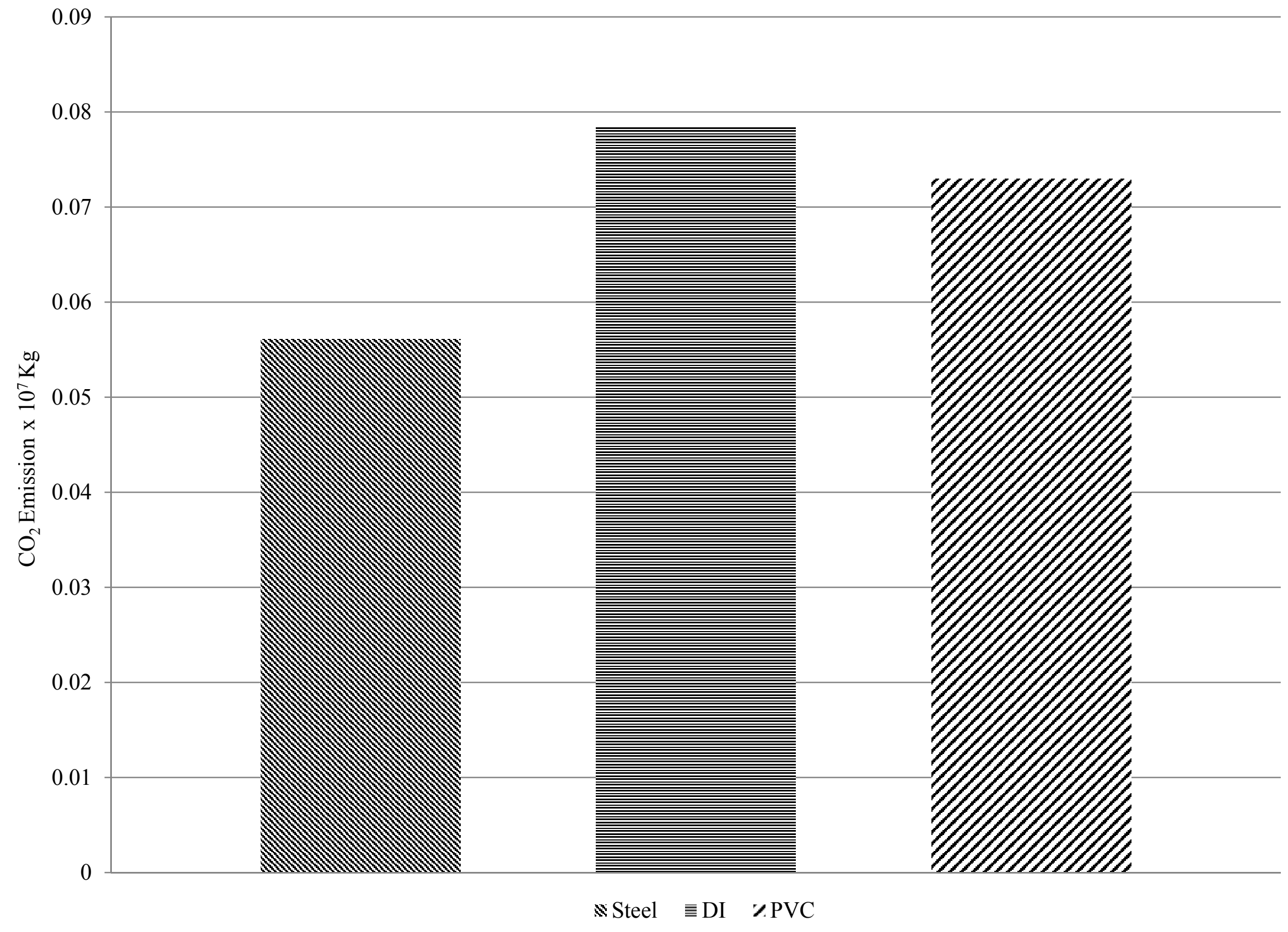

https://mc06.manuscriptcentral.com/cjce-pubs 


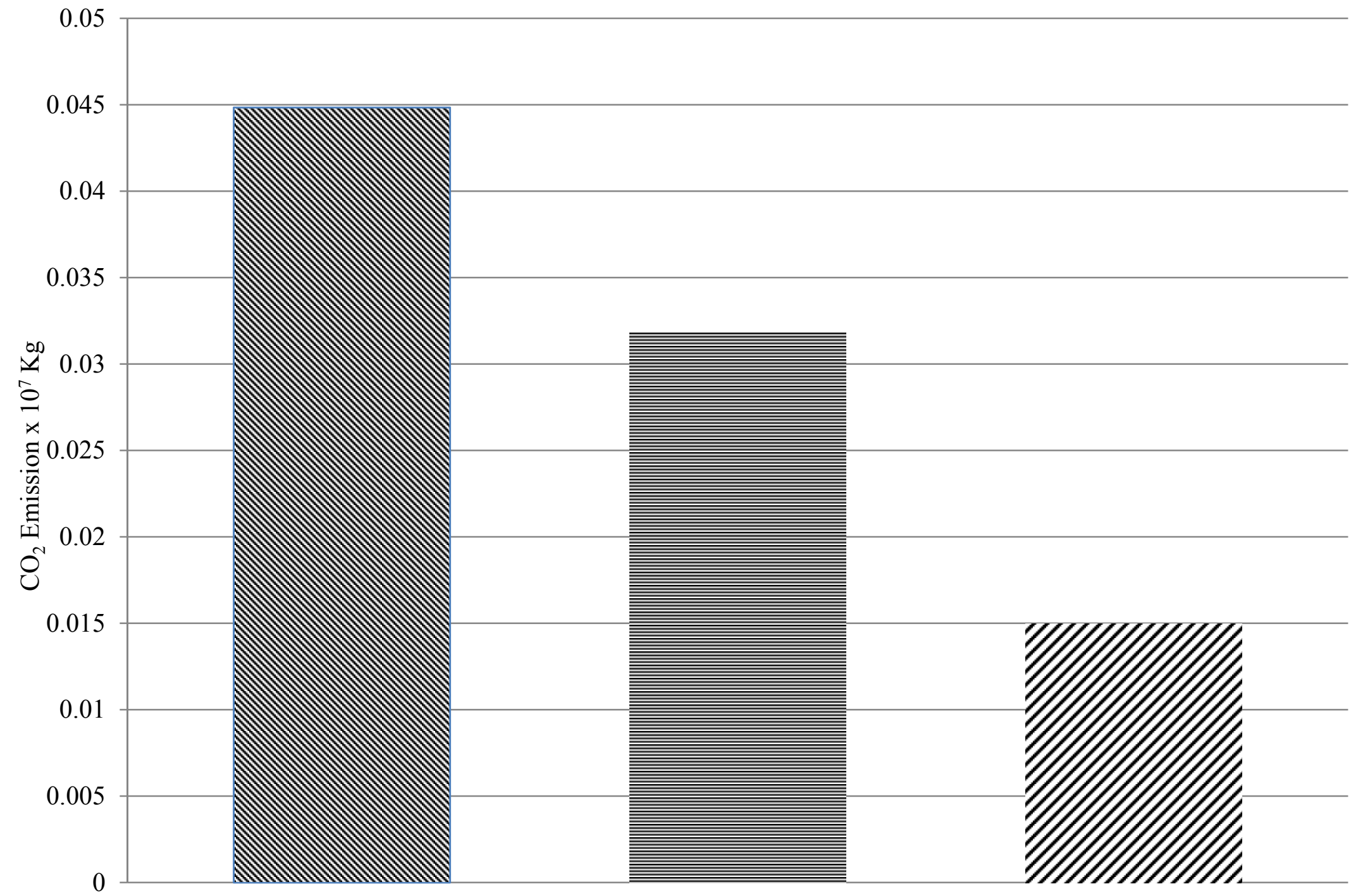

$\mathbb{\$}$ Steel $\equiv \mathrm{DI} \quad$ ‘ PVC 


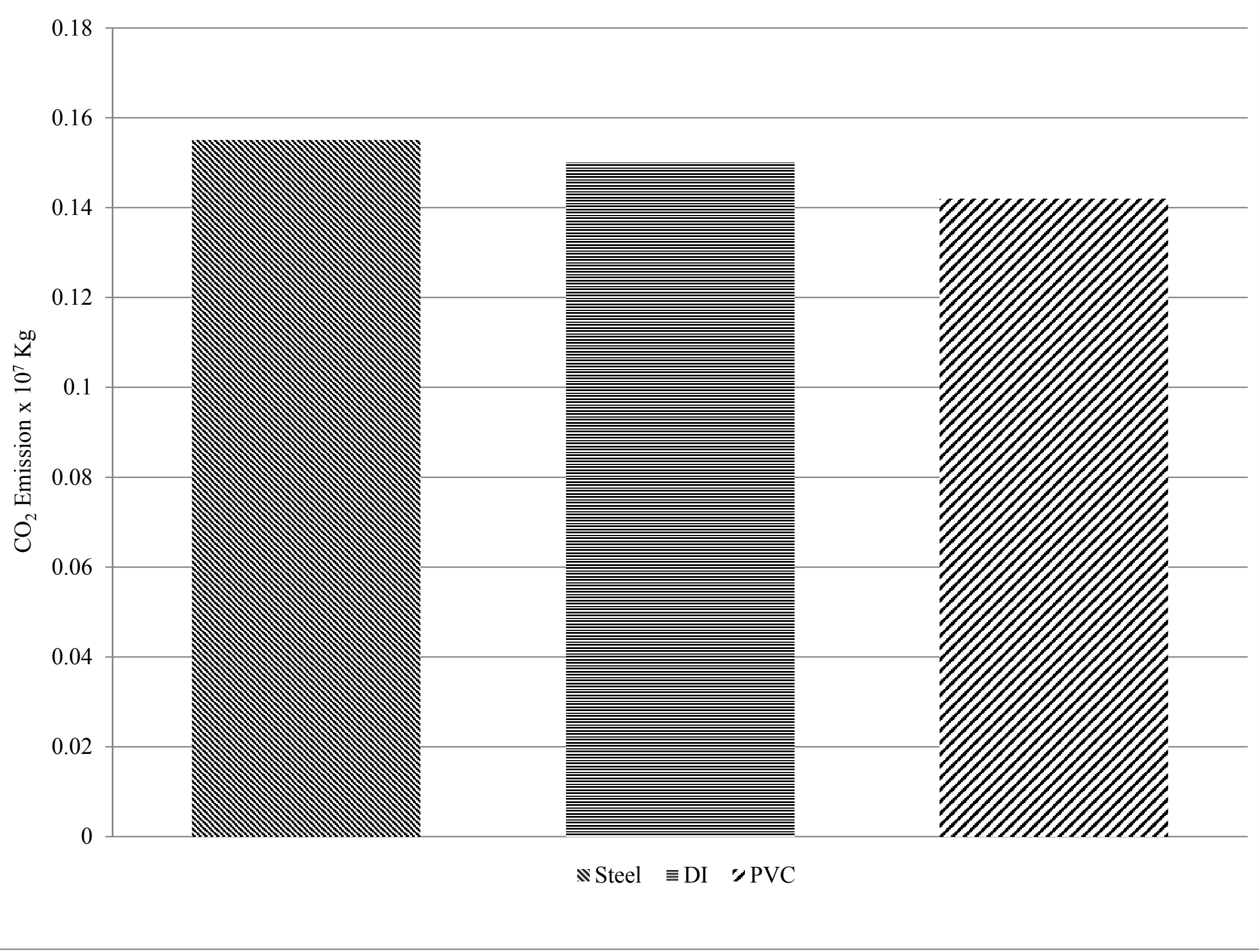




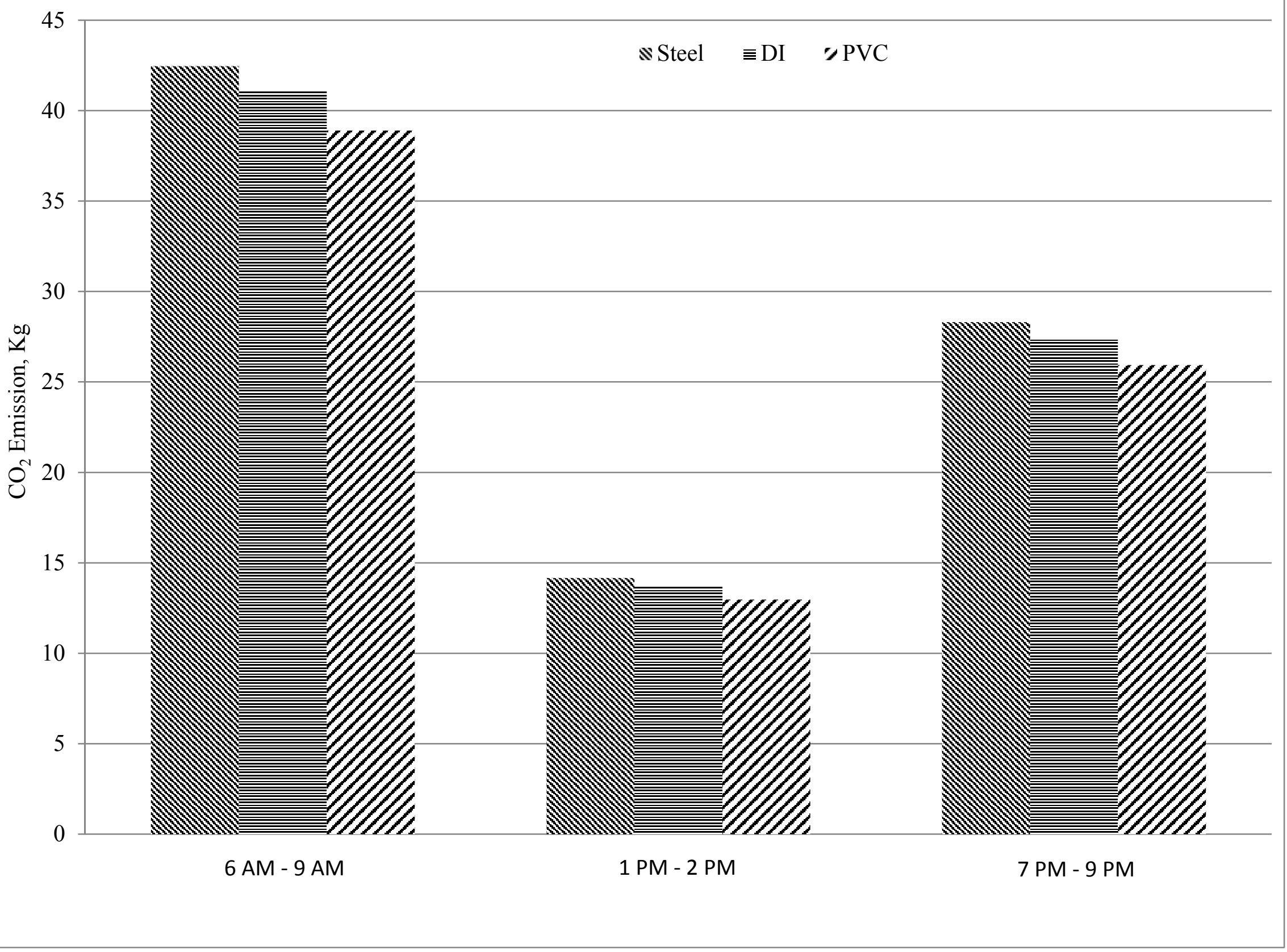

